\title{
NOTAS SOBRE EL TRABAJO Y LA LEGISLACION LABORAL EN EL REINO DE CHILE.
}

\author{
Dr. José Antonio González Pizarro \\ Escuela de Derecho-U.C.N. Antofagasta.
}

\section{I.Introducción.}

Antes de la llegada del español al territorio que conformaría la Capitanía General de Chile, el elemento aborígen se hallaba condicionado por el factor geográfico en la utilización de los recursos naturales y por diferencias en su estado cultural. Esto se reflejaba en la variedad de los instrumentos de trabajo empleados en todo el territorio actual de Chile.

Una actividad primaria netamente de subsistencia y con rudimentarias herramientas de faenas caracterizaba al grupo de pescadores, los changos, en el sector septentrional y central del espacio en cuestión. Esto se extendía también hacia los chonos y alacalufes, situados al sur de Chiloé, dispersos en estrechos, canales e islas y en los bordes del continente, viviendo de la extracción de peces y moluscos; utilizando balsas de lobos; los que tenían su hábitat más al norte, y canoas los pescadores meridionales.

En el interior del continente, los sistemas de medios de producción variaban notoriamente. Una mayor complejidad utilizaban los indígenas ubicados en el despoblado de Atacama, cuyo mayor centro era San Pedro de Atacama, donde, en la fase denominada Chincha-Atacama, se dedicaron a laborar metales alcanzando en los siglos IX-X una mayor producción de objetos de metales evidenciados en las sepulturas (1). El cobre fue el principal de los metales que emplearon, ubicándose su yacimiento más importante en Chuquicamata y explotando en la región del río Loa otros yacimientos de menor importancia (2).

El más numeroso conglomerado indígena, los araucanos, desarrollaron una agricultura a escala menor, limitada por el poco instrumental y una ganadería reducida a la cría del hueque o carnero de la tierra.

Indudablemente hubo una correlación directa entre la capacidad de organización social y sistemas de producción con los consiguientes padrones culturales y la explotación óptima de metales. De acuerdo con Osvaldo Silva Galdames (3), los atacameños y los diaguitas lograron constituir categorías tribales eficientes que incorporaron el estadio cultural más avanzado que representó la dominación incaica. Los mitimaes contribuye- 
ron en gran medida a una mayor organización productiva de las ya trabajadas minas de oro y plata en la región del valle de Copiapó, límite entre el despoblado y la fertilidad agraria del suelo.

La existencia de minas de plata fue abundante en el periodo incaico, pero la indiferencia a las mismas en el primer periodo de conquista y colonización, se debió al desprecio de aquel metal con relación al oro. Como apuntó Benjamín Vicuña Mackenna:

El conquistador incaico como el conquistador castellano no habían venido a tan apartado rincón del mundo en demanda de una materia que en aquellos tiempos, delante del tributo de Atahualpa en Cajamarca y de las paredes del templo del sol en el Cuzco, pasaba casi como materia vil y voluminosa. El oro era todo, y por esto hubo en Chile en remotos tiempos sólo una edad del oro"(4).

Tales minas de oro que encontró Diego de Almagro, refiere Fernández de Oviedo, estaban en los valles de Copiapó, Huasco, Coquimbo y hasta el río de Aconcagua, describiéndolas tan bien labradas como "si españoles entendieran en ello" (5). En su GEOGRAFIA Y DESCRIPCION UNIVERSAL DE LAS INDIAS, el cronista Juan López de Velasco confirmó lo anotado por Fernández de Oviedo, al referirse a la profusión de riqueza de oro en comparación a la plata (6). De la magnitud de la riqueza en cuestión Diego de Almagro, el Adelantado de Chile, dió testimonio (7).

El cultivo de la tierra fue trabajado de manera comunitaria en gran parte del territorio, descollando la forma socio-económica implantada entre los atacameños, los ayllos, los que harán uso del sistema de terrazas o andenes para el mejor regadío. Asimismo, cabe destacar a los pueblos de El Molle y Diaguitas que lograron perfeccionar una atractiva alfarería. De este modo, los impulsos técnicos y evolución de las estructuras sociales y eçonómicas se verificaron en los pueblos situados al norte del río Maipo (8).

La penetración de Pedro de Valdivia significó la incorporación definitiva de los recursos productivos al dominio de la Corona.

Empezaba una nueva etapa en la explotación de las riquezas del suelo y del sistema de propiedad con una evolución por consiguiente de los métodos de trabajo y su marco jurídico a lo largo de la dominación hispana. Realidad que afectó al componente indígena desde el desierto de Atacama hasta el río Itata y los residentes en Chiloé.

\section{La regulación del trabajo en los siglos XVI-XVIII}

Una primera visión de la nueva ordenación del trabajo en el territorio conquistado, se desprende de una carta del conquistador de Chile, Pedro de Valdivia, al emperador Carlos V, fechada en La Serena, el 4 de septiembre de 1545: hecha este verano pasado a las minas los anaconcillos que nos servían, y nosotros con nuestros caballos les acarreábamos las comidas, por no fatigen a los naturales, hasta que asienten, trabajando éstos que tenemos por hermanos... donde sacaban oro, han sacado hasta veinte y tres 
mil castellanos, con los cuales y con nuevos poderes y crédito para que me obligue en otros cient mill a las provincias del Perú... También repartía esta tierra, como aqui vine, sin noticia, porque asi convino para aplacar los animos de los soldados, y desmembré a los caciques por dar a cada uno quien le sirviese" (9).

En tan importante misiva al monarca español se desprende el trabajo minero y el sujeto a las mercedes de tierras, realidades económicas que le acarrearon más de una dificultad, fundamentalmente, la repartición de tierras, en Santiago, al poco tiempo de haberla fundado. Las espectativas depositadas en la extensión del territorio desde los chañares al río Maule y la cantidad de indios existentes había llevado a Valdivia a otorgar un número excesivamente mayor de beneficiarios de tierras. El 12 de enero, a instancias del Cabildo santiaguino, que solicitaba la reformación del repartimiento, estableció sesenta encomenderos que, no obstante, no solucionó el problema entre sus compañeros de armas no favorecidos. Más tarde, para hacer más eficaces tales encomiendas, las reformó, definitivamente, el 25 de julio, reduciéndolas al número de 32 , haciendo justicia plena a los integrantes de su empresa más emprendedores y de mayor afecto a su persona y hazaña conquistadora, quedando un total de 18 desposeídos de sus tierras e indios bajo amenaza de no alentar rumores e inquietudes entre el elemento indígena antes suyo, (10).

Esta política de Valdivia de repartir indios entre los vecinos de la ciudad la mantuvo en otras localidades. En Concepción distribuyó indios de acuerdo a la condición de vecinos, (11). En carta de 15 de octubre de 1550, desde esta última localidad, Valdivia le noticiaba al Rey: riquísima de minas de oro, que en ninguna parte se ha dado cata que no se saque, abundante de gente, ganado e mantenimiento, que noticia, muy cerca, de cantidad de oro sobre la tierra, y en ella no hay otra falta sino es de españoles y de caballos".(12).

Las reparticiones de tierras realizada por Valdivia abarcaron grandes extensiones, incluyendo accidentes geográficos y habitantes habidos, pero enmarcadas en lo que F.A. Kirpatrick ha calificado de "encomiendas sin tierras" (13), en relación a que las tierras concedidas, que ya suponían un atropello a la propiedad indígena, en el marco jurídico hispano, el título de encomienda no significaba la propiedad territorial para el encomendero. En general, como ha anotado Silvio Zavala, el derecho de propiedad territorial de los indios subsistía aun con la encomienda. Los indígenas podían trabajar su tierra a propio beneficio, pero no siempre se fue estricto en el cumplimiento jurídico de tal derecho, por cuanto muchas solicitudes de mercedes de tierras incluían terrenos, "de los indios encomendados" o procuraban convenir con los protectores de los indios, "para celebrar los contratos de traspaso de dominio" (14).

La encomienda que procuraba paliar la carestía de mano de obra en empresas agrícolas y mineras, mediante un sistema de trabajo forzoso, sin contrato de salario, en los comienzos de la conquista (15), aun cuando Pedro de Valdivia procuró ajustarse a la protección del indígena (16), fue motivo de grandes injusticias de todo orden entre los 
indígenas. El servicio personal del indio era un cruda realidad en actividades productivas y domésticas, en donde el rigor del castigo aumentaba los sufrimientos cotidianos, como lo testimonia Francisco de Victoria en carta al Consejo de Indias desde Lima, el 10 de enero de 1553 , indicando que el que tenía 100 indios echaba los 100 a las minas con mujeres y niños," y sino traen la tasa, palos y azotes y si an tomado algún grano y escondido, castígan los por ladrones y cortánles las narices y orejas y pónense enclavadas en un palo. La comida es en ocho meses que trabajan un cuartillo de maíz cada día" (17).

Aún cuando existían instrucciones precisas que a los caciques se les respetaran sus derechos de propiedad y no fueran incluidos como tributarios, hubo concesiones que no siempre respetaron tales prerrogativas y otras que las sostuvieron.

En un pleito de 1575, afirma Jerónimo Núñez que, "se me dan y encomiendan las dichas seiscientas casas, en que se incluye, como dicho tengo, el cacique é indios que pudo",(18), mientras, Luis Toledo expresaba, en febrero de 1560, que, "los lebos dichos... con sus caciques dichos... con todos los demás caciques e principales aqui nombrados con tanto que seais obligado á dejar a los caciques principales sus mujeres y hijos y los otros indios de su servicio, y á dotrinarlos y enseñarlos en las cosas de nuestra fee" (19).

La situación creada por las encomiendas varió de acuerdo a las discusiones y decisiones jurídicas que se llevaron a cabo en la metrópoli. En un primer momento se intentó suprimirlas en 1542, por medio de las Leyes Nuevas, para, posterior, incorporarlas como una realidad que había que aceptar mientras tanto.

En el caso de Chile hubo aspectos de concesiones surgidas de repartimientos generales en las que a los beneficiarios no se les entregó cédula de encomienda pero, de igual modo, tomaron posesión de sus indios. En muchos casos se crearon situaciones conflictivas, como ser la revocación por parte del Gobernador García de Mendoza de las encomiendas otorgadas por el repartimiento general de Tucapel al no concederles cédula de encomienda (20).

La actuación de Pedro de Valdivia en relación al resguardo de los derechos de los naturales y la repartición de la riqueza ha merecido la crítica, a pesar de algunas de sus medidas proteccionistas, como la prohibición de cargar los indios con un peso mayor de dos arrobas (21). Críticas que, sin embargo, reconocidas por algunos de sus biógrafos, son comprendidas al analizar el contexto singular de la conquista de Chile y las normas legales existentes en la época en España, todo lo cual va en favor de Valdivia, como sostiene Ramón L. Soriano (22).

Si las encomiendas fueron objeto de desánimo entre los españoles que acompañaron a Valdivia, los lavaderos de oro que existían desde antes de la llegada de Almagro, según hemos apuntado en líneas superiores, fueron los que abrieron una nueva fama a la Gobernación y apaciguaron los espíritus. A estos se agregaron otros que dieron sus frutos tempranamente. Próximo a Valparaíso el descubrimiento de Marga-Marga permitió 
a Valdivia ir a Perú en 1547 en busca de refuerzos con ochenta mil pesos de oro. Más tarde fueron descubiertos otros a medida que fueron asentándose las ciudades, como subrayó Gabriel Guarda en su Historia Urbana del Reino de Chile. A Quilacoya se sumaron las riquísimas minas de oro del sur, La Imperial, Valdivia, Calcoimo, Villarica, Relomo, Tucapel y Angol, etc., reportando cuantiosos beneficios a Valdivia y sus compañeros. El conquistador era dueño de la encomienda en los valles de Tucapel y Arauco, y del "mejor oro que se saca en todo el reino de Chile", apuntará Góngora Marmolejo (23).

Tal panorama de riquezas que iba aflorando el territorio de Chile llevó a las autoridades a atender la regularización de las faenas diversas, por cuanto, como acota Eugenio Pereira Salas, la débil estructura económica y social del país, "necesitaba tanto del trabajo agrícola en los campos para la subsistencia material como del oro para el pago de las transacciones mercantiles indispensables al tipo de vida urbana de la naciente colonia" (24).

A instancias de Valdivia el Cabildo de Santiago dotó de unas ordenanzas reales, "que han de guardar las personas que buscan minas de oro y las han de poblar en este Nuevo Extremo", con fecha 9 de enero de 1546. En ellas se regulaban los derechos de los descubridores, exceptuando los cautivos, a poseer tres minas, mediando la autorización de los reales oficiales, para coger oro, organizando la cuadrilla bajo el sistema de demora, permitiendo que el indio pudiera catar y si fuera primero, se estaque. La denuncia de descubrimiento de nacimiento de minas era fijado dentro del tercer día (25). Este fue de diez días en relación a las minas de plata, según determinaba el Cabildo el 9 de agosto de 1550, y también, con castigo por no anunciarlo a la justicia (26). En esta disposición también se señalaba que los descubrimientos, "fuera de media legua alguna mina de plata" por algún yanacona, indio o negro, sea el descubridor el "dueño de la tal pieza de indio, o negro o yanacona" (27), obligando al propietario de mina de plata u otro, "a tenerla poblada con cuatro yanaconas y cinco indios de repartimiento, o con un negro y dos yanaconas, con las herramientas que para ello fueren necesarias. $Y$ esto se entiende por la poca disposición de gente de indios que hay en esta tierra" (28).

El sistema de demora aplicado en las minas, consistía comúnmente en un trabajo de ocho meses entre fines de enero hasta fines de septiembre, pero con ligeras variantes en algunos casos.

En una relación destinada a la Real Hacienda se hacía constar que en las ciudades de Valdivia, La Imperial, Villarrica, Osorno y Castro, "se saca oro en las quebradas é arroyos, desde primeros de octubre hasta postrero de marzo" (29). Esta última ajustada a la modificación establecida por Santillan, de la que hablaremos más adelante.

La Corona se preocupó, como en todos los territorios del nuevo continente, de atender la eficiente extracción de metales como de proteger la calidad de súbdito del indio. A este respecto, vale tener presente que la propiedad minera, fundamentalmente la referida a las minas de oro, plata y azogue era de la Corona, como lo dispuso tajante- 
mente en 1559 Felipe II, (30). Así se entiende perfectamente la Real Cédula dirigida a Jerónimo Alderete, gobernador de Chile, sobre beneficiar las minas del territorio donde le señala, "entre otras cosas se ha tratado sobre lo concerniente á las minas de oro y plata, que me pertenecen en aquella providencia, y sobre la forma y modo que se tendrá en beneficiarlo con mas interés en su provecho y beneficio... para ayuda á las necesidades que como veis, tengo... con tanto que no se compellan no apremien mucho los indios" (31).

En relación a los naturales de las islas de Calbuco, Abtao, los indios chonos, los caucahues, la actitud de las autoridades fue diferente a la generalidad adoptada en otros lugares, por cuanto estuvieron al margen de las encomiendas y tributos, manteniendo la calidad de vasallos libres, decisión tomada, "por la fidelidad que demostraron y por la necesidad de mantener población grata en zona fronteriza", escribe Carlos Olguín (32). Tal situación de excepción contrastaba con el excesivo trabajo y dureza en el trato a que fueron sometidos los indios situados al norte del río Maule en el servicio personal, que no sólo aludía al trabajo forzado en minas, que había sido prohibido por Real Decreto de 1549 (33), sino, sometidos a trabajar en edificios y para servicios en casas de españoles, siéndole destinado a cada vecino treinta y cuarenta indios, y como denunció Mariño de Lobera", a esto respondieron ellos que no era razón que al trabajo excesivo a que les obligaba un rey infiel y tirano, les obligasen ellos que eran cristianos" (34).

El trabajo esclavista del africano estaba vedado en encomiendas, según la Real Cédula de 17 de diciembre de 1551 (35), no así en las minas. Esta mano de obra se empleó en Chile desde el momento mismo de la conquista, permitiéndose a los que eran negros libres, como Juan Valiente que acompañó a Valdivia, poder ser propietario de tierras.

El negro fue empleado en varias actividades desde faenas domésticas, cultivo de campos hasta el trabajo de minas, aunque en este último punto, el estar poblada una mina, o sea, trabajada por 8 indios o 4 negros, podía ser retenida por su actual usufructuario o concesionario (36).

En relación al trabajo del negro en encomienda, sancionado por la Corona, habría que mencionar que tal disposición no fue estricta. Un testimonio del empleo del negro en encomiendas de grandes extensiones y el uso del mismo en minas se verificó en Tarapacá (37).

La visita del Licenciado Fernando Santillán, Oidor de la Audiencia de Lima, en 1559, permitió la constatación oficial de la explotación masiva a que era sujeto el indio en las encomiendas. Su inspección fue mitigar tales formas de violencia laboral y prevenir el problema, ya patente en otras regiones, de disminución demográfica del indígena.

Santillán estaba enterado plenamente de la realidad del indígena en Perú, y pudo apreciar las diferencias fundamentales con el indio chileno. El primero, perteneciente a un estadio cultural superior, tenía conciencia de la importancia del almacenamiento de 
la producción, racionalizando su consumo y valorando la ganadería como fuente de alimentación y vestuario. El segundo, en un grado inferior, carecía de tales perspectivas.

Para Alvaro Jara, el esfuerzo de Santillán se debe destacar, por su aspecto innovador que apuntó a "realizar una reforma social y económica, una modificación del substrato indígena a su incorporación a las formas españolas de vida" (38). Apreciando la cruda realidad que juzga severamente (39), instruía Santillán que en las minas, "los indios deteneros de dos en dos meses y los lavaderos de cuatro en cuatro meses, y que el indio o lavador que anduviere una mina no lo metan la siguiente...y del oro que sacasen los dichos indios, el cacique tenga su quipocamayo y el minero y el encomendero cuenta y razón, y cada dos meses se traiga a la fundición desta cuidad y alli se divida" (40). La Tasa de Santillán determinaba una sexta parte del oro para el indio minero, el famoso sesmo, mientras el de encomienda con su participación, a través del salario, pudiera adquirir, "ropa y en ovejas o en lo que fuere más útil y provechoso para ellos", disponiendo, además, que en el sesmo del oro, dos personas, una nombrada por el cabildo y otra por la justicia mayor, con acuerdo del encomendero, "empleasen el dicho oro en ropa o lana o ganado, o en lo que desto pareciere más útil a los dichos indios", y para evitar irregularidades se entergase el oro en fundición, y no en polvo, así salvaguardar los derechos de la Corona, la de los indios, "y lo demás se entregue al encomendero, y que los mineros hagan ante todas cosas juramento de cumplirlo así" (41). Insistía Santillán en la obligación del encomendero de dotar de comida y herramientas al indio y el doctrinar a los indios en la fe católica. A esto se agregó la medida de que el indio, poco previsor, ayudare a sembrar y coger al encomendero y se guardara la tercera parte de su trabajo en depósito. Un articulado fundamental en tal innovación fue dejar tasados a todos los indios y pueblos, ordenando que los indios destinados para el trabajo fueran recogidos entre los 18 años y los 50, prohibiéndose hacer laborar a los menores de 18 y mayores de 50 años como, asimismo, la mujer quedaba fuera del mundo laboral, excepto una india por cada 10 indios, dados por los caciques para, "que les aderece la comida" (42).

El que trabajaba en mita no podía ser ocupado en otra faena aparte de su destinación, como también, que los indios yanaconas o naturales del Perú pudieran regresarse. A los que trabajaban en cosecha se debía dar a cada uno una manta, "a los carreteros e indios que guarden ganados y viñaderos e de servicio de casa, a cada uno un vestido entero en cada un año y dos puercos y una cabra; y a las mujeres que serviesen en casa, en cada año dos vestidos enteros de algodón" (43).

El sesmo del oro se convirtió en la principal fuente de ingreso de las cajas de comunidad indígena. Este beneficio en la visión de Santillán debía no sólo ser la expresión de una protección del indígena sino un intento de modificar los hábitos económicos del mismiu $(+4)$. Sin embargo, este esfuerzo humanitario y realista de Santillán se estrelló contra los intereses de mineros, encomenderos y mercaderes (45). 
El encomendero y minero, el mercader y el militar se interesaron solamente en que el indio se dedicara a actividades primarias de subsistencia y a brindar mano de obra sumisa en el marco de una economía autárquica y cerrada (46).

El aspecto señorial reflejado en la economía también se proyectaba en el orden social. A este respecto, José Armando de Ramón Folch, ha comprobado el íntimo nexo entre el poderío económico, basado en la tenencia de la encomienda, y la conformación de un grupo social principal en la sociedad santiaguina en el siglo XVI. En la etapa final del siglo XVI, antes del desastre de Curalaba en 1598, Ramón Foch distingue los grupos siguientes:

$\begin{array}{llllllll}\text { Rango alto № } & \% & \text { Rango medio } & \text { № } & \% & \text { Rango bajo } & \text { № } & \% \\ \text { Encomendero 113 } & 71 & \text { Mercaderes } & 33 & 47 & \text { Artesanos } & 22 & 7 \\ \text { Función.Altos 40 } & 25 & \text { Func.Medios } & 27 & 38 & \text { Func.Bajos } & 6 & 21 \\ \text { Militares Alt. 7 } & 4 & \text { Milt.Med. } & 11 & 15 & \text { Milit.Bajos } & 1 & 3,(47)\end{array}$

Tal conformación social aristocrática era la aplicación de un modelo de organización señorial que los conquistadores habían observado en sus tierras de orígen, principalmente, de Extremadura (48).

El encomendero tenía a su cargo gran cantidad de mano de obra. En un primer momento del repartimiento fluctuó entre mil y diez mil indios. La repartición de solares en las ciudades afectaba preferencialmente a los conquistadores, que constituidos en vecinos, participaban en la conformación del Cabildo, (49). Tal situación estaba refrendada por la Corona la que, a comienzos del siglo XVII, exigía el cumplimiento de que los premios y repartimientos de encomiendas se prefiriera a los hijos y nietos de conquistadores, (50).

El proceso de urbanización en que se desenvuelve el territorio, principalmente, bajo el imperativo militar, evidenciado en las ciudades sureñas, Concepción, Valdivia, Osorno, etc., promovió una mayor complejidad de relaciones económicas y sociales en gran medida bajo la fiscalización del Cabildo que, también, atendió la estabilidad entre el consumo y la exportación (51).

En las ciudades principales el trabajo se manifestaba en una variedad de oficios, distinguiéndose los oficios eclesiásticos y los seculares (52). En Santiago se tiene conocimiento desde tiempos de Valdivia, de la existencia de los oficiales de sastre, carpinteros, a los que el Cabildo, a falta de fiel ejecutor, intervino en la fijación de sus precios por cuanto, "elevan los tales oficiales muy desáforados precios, más de lo que está proveído o mandado por los señores de este Cabildo" (53). Como también, antes, habíalo determinado frente a los oficiales herreros (54).

A estos se sumaban alarifes, albañiles y carpinteros, en los cuales participaban españoles, indios y negros, además de mestizos y mulatos, conformando el artesanado 
urbano y el inquilinaje rura!. Al respecto, apuntó Gabriel Guarda que, "los prejuicios existentes entonces sobre las actividades propias de hidalgos, que excluían los oficios mecánicos, detendrían en su raíz esta honrosa diversidad de ocupaciones" (55). Una gran perfección de oficios artesanales ofrecieron los jesuitas bávaros, encabezados por el P. Carlos Haymbhausen, entre 1748 y 1767 (56).

El territorio dividido en varios términos experimentó una fluctuación demográfi$\mathrm{ca}$, que repercutió en las actividades, muy acentuada en el curso del siglo XVI, viendo sensiblemente disminuída su población indígena. De acuerdo, con la estadística brindada por Rolando Mellafe, Chile tenía la siguiente población en ese siglo:

\begin{tabular}{rrrrrr} 
Año & Europeos y criollos & $\begin{array}{c}\text { mestizos } \\
\text { blancos }\end{array}$ & indios & $\begin{array}{r}\text { negrosy } \\
\text { mestizos }\end{array}$ & total \\
1540 & 154 & \multicolumn{1}{c}{. } & 1.000 .000 & 10 & 1.000 .164 \\
1570 & 7.000 & 10.000 & 600.000 & 7.000 & 624.000 \\
1590 & 9.000 & 17.000 & 549.000 & 16.000 & 582.000 \\
1600 & 10.000 & 20.000 & 500.000 & 19.000 & 549.000
\end{tabular}

(57).

La importancia de los mercaderes en la estructura económica-social quedaba asegurada por la relación que ligaba a la gobernación con el Virreinato del Perú, tanto por razones económicas como administrativas. Del mismo modo, había un intercambio con la audiencia de Charcas, y con las provincias transandinas. Existían rutas que comunicaban con Potosí a través del despoblado de Atacama y con la provincia de Tucumán.

Con Potosí había un flujo comercial de vino, cordobanes, sebo, hilo zapatero y también con destino a Lima. De Tucumán se importaba tejidos, bastos de algodón, ganados y en algunos casos se ampliaba el circuito comercial, "para entroncar directamente con el eje Lima-Potosí" (58), lográndose ganancias líquidas de un cuarto o un tercio de la operación. Tal comercio estaba fuertemente estimulado por la bonanza aurífera del siglo, que dominaba la actividad económica, aunque se presentaba en declinación, si comparamos que la media anual de $2.000 \mathrm{~kg}$. de oro entre 1545 y 1560 , pasaría a ser de $500 \mathrm{~kg}$. a partir de 1560 hasta fines de siglo.

La tasa de Santillán obtenía en 1561 la aprobación del Rey. El gobernador de Chile bajo influencia de tal predicamento sugirió a los encomenderos y otros españoles que fijaran su atención en la provisión de negros, "para el beneficio de las minas de suerte que los naturales sean más sobrellevados" (59). Aquello explicaría el número creciente de negros en la estructura poblacional pero, también, un nuevo problema humano que fue denunciado por la Iglesia chilena, en especial, por el Obispo Francisco de Salcedo en el siglo XVII (60). 
Aun cuando fueron en 1561 refrendados los dictámenes de Santillán, por el Rey, la reacción de la sociedad chilena frente a la innovación no se hizo esperar. En ese año el gobernador Francisco de Villagra ordenaba que los indios labraran, en minas de oro, "desde principios de febrero y salgan en fin del mes de septiembre" (61), manteniendo la prohibición de todo negro", de ninguna condición que sea no puede ser minero ni coger oro con cédula ni tomar mina" (62), rebajando la ganancia o participación del indio a la octava parte y aumentando el número de los mismos destinado a la demora. Tales directrices fueron rectificadas por Pedro de Villagra, "aprobando las del licenciado Hernando de Santillán en favor de los indios de Chile", el 24 de agosto de 1563 (63), reduciendo la demora de ocho a seis meses y nombrando protectores de indios en cada una de las ciudades del reino.

Las desigualdades en el trabajo se mantuvieron. Mientras los oficios especializados por poseer la técnica europea gozaban de un buen salario y de un trabajo contratado, que se extendía a los yanaconas y a los indios alquilados, el común de los indios, y el más numeroso, era afectado por un salario ambiguo del cual Rolando Mellafe ha indicado que fue expresado de tres maneras; a) representando parte del tributo o capitación; b) como salario colectivo; c) como simple arrendamiento de fuerza de trabajo, (no como prestación remunerada) (64), al esclavo negro le quedaba reservado fuertes castigos por huidas, a discreción de su amo, según determinaba la ordenanza de Melchor Calderón de 10 de noviembre de 1577 (65), como, asimismo, se mantenían las diferencias ante la responsabilidad penal (66).

Las irregularidades en el cumplimiento de Tasas y Ordenanzas en favor del indígena prosiguieron bajo diversas formas. El encomendero de modo especial representaba la mayor conculcación de las disposiciones de la monarquía en favor de un buen trato a los naturales en el trabajo, situación que aparejó una enérgica prédica evangelizadora en determinados personajes de la Iglesia, y una actitud de denuncia de atropellos de ésta como institución. Entre los predicadores que clamaban por una justicia social sobresalió Fray Gil González de San Nicolás que llegó a encarar, en defensa de los naturales, la legitimidad de la guerra que permitía atropellos a éstos (67). Los franciscanos también se sumaron a la defensa de los naturales criticando el mal trato, reconociendo, al mismo tiempo, las acciones en favor de estos, como se desprende de la carta de tres franciscanos a Las Casas de 6 de marzo de 1562, aludiendo a la magnanimidad de D. García Hurtado de Mendoza frente a los aborígenes (68).

Francisco de Villagra también ordenó desposeer de indios, chacras y tierras a los vecinos de Santiago beneficiados por Hurtado de Mendoza. Al respecto, el licenciado García de Castro hacía presente, en 1566, que tales despojos cometidos no sólo por Francisco de Villagra, sino por el mismo García Hurtado de Mendoza y el primo de Francisco de Villagra, Pedro de Villagra, hacían necesario el establecimiento de una Audiencia en el país (69). La Audiencia era el cuerpo requerido para el control legal de las irregularidades. De acuerdo, con Las Nuevas Leyes de 20 de noviembre de 1542, tenía 
facultad de gobierno relativo a los indios y competencia en el buen tratamiento y cuidado que se cumplieran las leyes protectoras (70).

La Audiencia quedó establecida en Concepción, virtual capital militar del reino, el 27 de agosto de 1565, incidiendo en la importancia de aquella ciudad y fiscalizando a los encomenderos, a los que en 1571, puso en "harto aprieto a todos los encomenderos haciéndoles pagar todo lo ganado" (71).

Las disposiciones que corren desde 1563 hasta 1580 reforzaron la tributación de los indios, el servicio personal, la restauración de la demora de ocho meses. Unas, en el espíritu de protección indigenista, como era la Real Provisión de 28 de enero de 1568 , (72) otras permitiendo la libertad de acuerdos de trabajo para el indígena, sin que su encomendero se lo impida, y siempre que no esté destinado a la mina, concesión determinada para el repartimiento de Santiago de 30 de junio de 1568 (73). Sin embargo, la nota que, nuevamente, prevaleció fue la injusticia sobre el indígena como la de obligarlo a pagar tributos de pesos de oro, ropa, trigo, cebada y miel estando dentro de una tarea de encomienda, donde la tasación de tributos no los eximía del servicio personal. Esto aun cuando existía la Real Cédula de tasación, "de los tributos que deben pagar los indios del Obispado de La Imperial de 17 de julio de 1572" (74), que procuraba rectificar tales anomalías ante las protestas del Obispo de La Imperial Diego de Medellín, el que era testigo de los trabajos ilegítimos, sustracción habitual y total del salario indígena y de la "coalición de encomenderos y autoridades locales" (75). La actuación de Diego de Medellín fue elocuente y le acompañó en su afán indigenista el Obispo Antonio de San Miguel.

Se debe a la influencia de Diego de Medellín la Tasa realizada por Martín Ruíz de Gamboa, promulgada el 7 de mayo de 1580. Los fines que perseguía la Tasa los ha resumido Agata Gligo del modo siguiente: a) El servicio de Dios Nuestro Señor; b) Aumento de su Santa Fe Católica; c) La conservación de los indígenas del Reino; d) La pacificación de los indios rebelados; e) Mejoramiento del estado económico de los indígenas; f) Mejoramiento del estado social y político de los naturales; g) El sustento de los habitantes del reino (76).

La Tasa establecía que serían indios tributarios los mayores de 17 años y menores de 50 años, exceptuando los que padecían de enfermedad que impidiese el trabajo. Cada indio tributario debía entregar anualmente ocho pesos oro, "el monto fijado debía completarse en oro y en especies" (77), asimismo, aportar la cantidad de "un peso de buen oro" por cada indio tributario con el fin de costear las herramientas necesarias para el trabajo, las comidas de los indios, los salarios de los corregidores y las cuotas de la comunidad" (78).

El indígena, al que no se le constreñía el trabajo para el encomendero, debía cubrir, con su tributo, el salario del sacerdote doctrinero con un peso, y el tributo del encomendero, con siete pesos. A tal obligación se le sumaba su contribución de mantener 
"tambos", posadas del camino. A la supresión del servicio personal agregó la disminución del período de la demora, a cuatro meses, de junio a septiembre. Los indios debían permanecer en sus pueblos, que la Tasa había reglamentado con minuciosidad, creando los cargos de corregidor y administrador y, como anota Silva Vargas, "eligiendo entre los indios dos alcaldes y un alguacil" (79). En los pueblos de indios, el elemento indígena podía sembrar "para si y para sus tributos... y que se hagan sementeras para la comunidad" (80).

La Tasa de Gamboa suscitó reacciones diversas. Su propio autor estaba satisfecho de su obra, mientras el clero se opuso a la alta tributación a que fue sometido el indio; el encomendero y demás población española la resistió por cuanto mermó el poderío de señorío absoluto que habían gozado, que repercutió favorablemente en la aceptación de tales medidas entre las naturales de Chile (81). Así reflejaba la situación el infatigable Diego de Medellín al Rey en 1585, respecto a la reducción indígena en pueblos, " que los han de reducir con achaque de la guerra, o no quieren o no han podido reducir". Tales conceptos los volvía a repetir en enero de 1587 (82).

A los dos años de haberse establecido la Tasa, el Rey agradecía al Obispo de La Imperial, pero amablemente le recriminaba que no, "le hubiere dado cuenta del inhumano tratamiento a que los encomenderos de Chile sometían a los naturales" (83). La Tasa de Gamboa fue derogada por el Gobernador Alonso de Sotomayor en 1583 y se volvía a, "un sistema similar al de Santillán, aunque autorizando un número mayor de indios para concurrir a las minas" (84).

El indio, como acusaba Diego de Medellín, seguía siendo objeto de abusos, despojos y mortandad, ésta última, era la respuesta de la visible disminución del indio en el siglo XVI y su impacto en la mano de obra disponible. Situación que el gobernador Martín García Oñez de Loyola explicaba en relación a las borracheras indígenas, causa de la mortalidad, y la disminución de la procreación. La disminución de indios de paz en encomiendas era alarmante, de 450.000 en 1570 habían pasado a 420.000 en 1590, para llegar en 1600 a la cifra de 300.000 (85).

El 4 de febrero de 1593 el gobernador Martín García Oñez de Loyola, en unas "Instrucciones y ordenanza para los Administradores de Pueblos de Indios", determinaba la prohibición de "sacar indios reservados para el servicio personal de los encomenderos ni más servicio de el que les estuviere señalado", como también de trabajar fuera del pueblo sin autorización del protector, disponiendo que, "los indios carpinteros de carretas las hagan para sí y para la comunidad, pagándole tributo a su encomendero" y que los indios cimarrones y vagabundos "que anduvieren huidos de sus pueblos los envíe a ellos", destinando para atender el tambo a indias, solteras, de más de cuarenta años, excluyéndose las mozas y las sospechosas (86).

Un factor relevante y crucial que afectará al mundo laboral fue la continuación de la guerra de Arauco, que fue asumiendo proporciones dramáticas para la estabilidad 
del Reino. Aquello no sólo afectó la sicología del español avecindado en el territorio y en la planificación de los asentamientos urbanos, sino que se proyectaba en una merma constante de los recursos económicos del reino y del virreinato del Perú. Varias consideraciones de índole espiritual -no dejar abandonados a los indios convertidos-, laboral mejor trato al natural - y castrense - precaverse de una buena defensa ante las amenazas inglesas, etc., fueron estimadas por las autoridades (87).

La obligación militar que tenía contraída el encomendero no cubría las necesidades en tal orden. De allí lo urgente que el Virreinato del Perú socorriese con hombres, 300 soldados, era un acuerdo de la Audiencia de Lima, el 30 de junio de 1591, además, de auxilio monetario, a una media de 30.000 ducados anuales.

El 23 de diciembre de 1598 ocurría el desastre de Curalaba con la muerte del gobernador Oñez de Loyola. Fue el gran descalabro. Como escribe Jaime Eyzaguirre, "concluye así el siglo XVI con la ruina de gran parte de la obra española en Chile" (88). A partir de Curalaba, las controversias respecto a la esclavitud del indígena dominarán la vida política, militar, civil y eclesiástica. Como apuntó Alvaro Jara "aunque en Chile se practicó la esclavitud de los indios con mucha libertad y desde antes de la muerte de Oñez de Loyola, sin embargo no se buscó una justificación en doctrina de tales prácticas sino después de Curalaba" (89). En tal polémica se dieron motivos económicos, espirituales, pero también temores de que la codicia de ganancia llevaría a la venta de esclavos, exportarlos, y quedaría despoblada de naturales la tierra afectando al sistema productivo, como sostuvo Domingo de Erazo (90). Como respuesta a este estado de convulsión, se estableció el real situado, el 24 de marzo de 1607, dando origen al ejército permanente, que afectó no sólo al erario fiscal sino a los recursos humanos de la Corona (91).

Frente a la esclavitud la Corona mantuvo una política mutable. En 1605 se prohibía la esclavitud y venta de los indios tomados en guerra (92). A los dos años, el Consejo de Indias recomendaba la esclavitud (93), y finalmente, por Real Cédula de 26 de mayo de 1608 los indios de guerra, "sean dados por esclavos, no reduciéndose al gremio de la Iglesia antes de venir a manos de las personas que los tomaren" (94). Pero, no era la última página sobre el tópico como veremos.

La llegada de la Compañia de Jesús en 1593 fue de especial gravitación en las decisiones que se adopten sobre la materia de Chile. Rápidamente hizo sentir su influencia en un mejor tratamiento de los indígenas, considerando en 1608 injusto el servicio personal, otorgando la libertad de los indios yanaconas y un salario equitativo (95).

Tal disposición de los jesuitas no sólo se centró en las condiciones laborales sino que la extendieron al campo militar, destacándose la figura del P. Luis de Valdivia quien logró del Rey Felipe III, en 1612, la transformación de la guerra ofensiva en defensiva y en calidad de Visitador General de las provincias de Chile, estudió la tasa de tributos con vista a suspender el servicio personal definitivamente. En tal período también intervino 
el gobernador Alonso de Ribera, brillante militar. La muerte del gobernador en 1617 y el deceso de Felipe III en 1621, produjeron un cambio en tales rumbos, decretándose en 1625 la guerra ofensiva y la aplicación de la esclavitud legal autorizada en 1608, que se había suspendido en el curso de la guerra defensiva (96). Quedaba, la impronta del quehacer del P. Valdivia en las disposiciones laborales establecidas por el Virrey del Perú, Francisco de Borja, Príncipe de Esquilache, de 28 de marzo de 1620, que había prohibido el servicio personal y creado un tributo pecuniario al año que afectaba a los indios mayores de 18 y menores de 50 años, estableciendo un trabajo libremente pactado, (97). Tales disposiciones legales eran convertidas, dos años más tarde, en Tasa Real.

Esta política fue refrendada por la R.C.de Felipe IV, de 17 de julio de 1622, que prohibió el servicio personal en Chile, declarando "por nulos, y de ningún efecto todos los títulos, y derechos, que á él han pretendido tener los Españoles por encomienda, costumbre, prescripción, amparo, ó por haberse poblado en sus chacras, ó estacas, ó por habérseles enseñado oficio, criado, ó nacido en sus casas, ó por haberlos aprisionado en la guerra antiguamente, comprado o trocado, ó de otra qualquiera forma que sea" (98).

Reparemos que la importante Real Cédula en comento iluminó otras materias que fueron recogidas en casi todo el Título 16 del Libro VI de la Recopilación de 1680 , respecto al buen tratamiento de los indios de Chile, los que eran encomendables y los que pertenecían al Patrimonio Real (99).

El decreto real de 1625 permitió bajo formas legales una secuela de abusos como era de prever. No obstante, Felipe IV ordenaba en 1633 al gobernador de Chile, Lasso de la Vega, "tasar los tributos de los indios de su jurisdicción y asegurar la abolición del servicio personal", mandato que el gobernador cumplió en abril de 1635, al dictar una Tasa, "para el desagravio de los indios naturales del en virtud de Cédula Real de Su Majestad", permitiendo que todos los indios, "así de pueblos como los que conforme a la Real Tasa... Gocen de la gracia, merced y entera libertad que S.M. con su acostumbrada clemencia les ha concedido quitándoles el dicho servicio personal y que sean tratados, habidos y tenidos y comúnmente reputados como los demás vasallos libres que Su Majestad tiene en este reino" (100). Los encomenderos, además, de respetar al indio como vasallo del Rey y persona libre, no podía hacerlo trabajar en domingo y fiesta, como de igual modo, "ni de noche ni en las curtidurías en tiempo de invierno" (101). Los indios quedaban autorizados para alquilarse libremente con cualquier persona próxima donde estaban asentados de preferencia con sus encomenderos, "en el dicho servicio y al alquiler por el tiempo necesario para pagar su tributo y lo señalado al doctrinero" (102).

La tasa de Lasso de la Vega estimada como una "hábil transacción entre el sistema del tributo y el del servicio personal" (103), rigió durante todo el siglo XVII en materias de tributos indígenas, es decir, de diez pesos de a ocho reales, aun cuando en la Recopilación de 1680 se manifestó el anacronismo al considerar, únicamente, la de Esquilache.(104). 
Los protectores de indios junto a los corregidores y administradores de pueblos estuvieron a cargo de la dirección de las cajas de comunidad, cuyos ingresos se componían de los sesmos, ventas de cosechas y ganados, ventas y arriendos de tierras indígenas, y de los corridos o intereses de censos. Estos últimos fueron a favorecer directamente a la sociedad criolla y española del país. Los censos comúnmente consistían en la entrega de sumas a dueños de bienes raíces, a cambio de una renta del $5 \%$ anual que era garantizada por dicha propiedad. Tal sistema era condicionada por la "disminución y desaparición paulatina de los pueblos de indios en la zona central... parecía aconsejar esta clase de inversiones, ya que ellas permitirían conservar en su integridad el patrimonio original, aunque desaparecieran sus dueños" (105).

La esclavitud indígena y, también, africana, dominó la problemática laboral en el curso del siglo XVII. El tráfico de negros quedó casi oficializado a partir de 1608 por las gestiones del P. Luis de Valdivia en favor del indio. El elemento negro fue utilizado de modo preferencial en las propiedades de la Compañía de Jesús, como ser, Calera de Tango, hacienda de Bucalemu, etc., totalizando 1.200 al ser expulsada tal Orden de Chile en 1767 . El negro en aquellas propiedades gozó de un buen trato y consideraciones inusuales en aquella época.

El africano fue empleado en el campo como peón y en oficios domésticos en propiedades urbanas. Hacia 1620 la cantidad de negros y mestizos era de 22.000 en un total poblacional de 557.000, y en 1650 sumaban 5.000 en un universo de 550.000 habitantes (106).

En tal tráfico algunos vieron la solución del problema indígena y de la guerra.

Alonso González de Nájera fue el máximo exponente de tal posición. Para González de Nájera se debía hacer una guerra a fondo contra los indios y someterlos a esclavitud donde, "los comisarios que hubieren conducido los negros a Chile, podrán sacar los indios y llevarlos en colleras hasta el embarcadero de Buenos Aires, y allí en navíos por el río de la Plata a vender al Brasil... será la parte más cómoda para deshacerse destos esclavos de Chile, a causa de ser donde se han de comprar o trocar por los negros... El trueco que en Chile se hiciere durante el limpiar aquella tierra de esclavos, podría hacerse dando dos o tres indios por un negro, con que se satisfaciese su precio; y acabados los esclavos indios, se podrán fiar y vender en Chile los demás negros que se llevaren", (107).

Las opiniones de González de Nájera no surtieron efecto en la sociedad criolla y española. Fue en el curso del siglo XVII donde la sociedad chilena se consolidó y por consiguiente la colonización española, aunque hubo de aguardar más de algún levantamiento general de los indios. No obstante el status quo de la guerra de Arauco no se llegó a adoptar las drásticas medidas preconizadas por el autor del Desengaño y reparo de la guerra de Chile, por el contrario, la Corona siguió demostrando un celo por el buen trato del indígena, acogiendo solicitudes de los jesuitas que abogaban por ello. En algu- 
nos casos al ser dispar las opiniones sobre algún tópico, el Rey puso en manos del Virrey del Perú la solución, como aconteció sobre la discusión si era necesario herrar o no a los indios que se tomaron prisioneros (108).

A la preocupación regia se sumaba la perseverancia y vigilia sobre el buen tratamiento de la Iglesia local. Respecto del tráfico de indios huarpes de Cuyo para ser incorporados como mano de obra en las haciendas, la voz del Obispo Francisco González de Salcedo se alzó para condenar tal acción, incluyendo una cláusula al respecto en el Sínodo de 1626 (109). La postura del Obispo le acarreó dificultades con la Real Audiencia y, obviamente, con el grupo de hacendados. Posteriores Sínodos fueron ocasión, nuevamente, de roces entre la jerarquía eclesiástica, que firmemente sostuvo su preocupación por el indio, y las autoridades civiles y parte de la sociedad española cuestionada (110). Más tarde, la denuncia del Obispo de Santiago sobre la misma materia al Rey era el motivo de la dictación de la Real Cédula "acerca de los excesos que cometen los gobernadores, corregidores y alcaldes mayores contra los indios" de 27 de agosto de 1676 (111).

A la riqueza aurífera le sucedían otras actividades económicas, centradas en la explotación cuprífera y la agricultura. En esta última, se destacaba la ampliación de los campos cerealistas ocupando grandes extensiones en el centro y norte del país, proveyendo de fuente de trabajo a considerables contingentes, repercutiendo en las exportaciones al Virreinato del Perú, principal mercado, al que abastecería de sebos y de trigo, (112).

Los mayorazgos iban configurando la gran propiedad a lo largo del territorio, como formas de perpetuidad de las encomiendas como había ordenado la Corona a fines del siglo XVI, mientras acontecía el saneamiento de títulos de dominio y mercedes de tierras en el siglo XVII dando lugar a la composición de tierras (113).

Fue en el siglo XVII donde el sentimiento de chilenidad se acrecienta. Para Francisco Núñez de Pineda y Bascuñan, los males de la nación había que buscarlos en el carácter de extranjeros de los gobernantes, o sea, no nacidos en el territorio, en la esclavitud a que se sometía al indio y la explotación descarada del mismo en faenas diversas, que eran las causas del estado de rebelión general de indios de 1655 (114). Aun cuando Pineda y Bascuñán se quejaba de la falta de energía del clero en denunciar los vejámenes de que eran objeto los indios, discutible afirmación, en todo caso, se vio reparada por la fuerte personalidad del jesuita Diego de Rosales, quien logró de la Reina Mariana de Austria, el 20 de diciembre de 1674, la real cédula que resolvía: que no se hagan esclavos los indios de ese reino con pretexto alguno en ninguno de los tres casos que queden expresados, y rogamos y encargamos (como lo hago) dispongáis sean tratados con el amor y benignidad que se debe y está mandado, como a vasallos del Rey mi hijo, procurando que no sean oprimidos ni molestados, sino que se cuide de su alivio y conservación, por lo mucho que importa su aumento, para lo cual procederéis contra los curas y doctrineros que les hiciesen malos tratamientos, aunque sea con el pretexto de decir que son enemigos y que ocasionen y hacer guerra" (115). 
La abolición de la esclavitud indígena fue la culminación de una acción de la Compañía de Jesús en favor de los indígenas. Ya en 1624 al establecer las misiones circulares, en el marco de una mayor evangelización, designaron a un natural a cargo de las capillas cruzadas que se denominará "fiscal", el cual quedará al margen de toda tributación, siendo motivo de dificultades con los encomenderos que se oponían a tal merma de indígenas para tal cargo (116).

A la medida de la Corona relativa a la prohibición de la esclavitud, se agregó al año siguiente, la concerniente a que, no pudiese azotar ni consentir azotasen, ni cortar el pelo, ni hacer otro ningún castigo a ningún indio" (117). Al año siguiente, exigía que en el cobro de los censos de indios se les diera "la debida inversión" que no "se empleaban en utilidad de los indios, así vivos a como difuntos" rezaba la R.C. de 9 de agosto de 1676. Tres años más tarde, se ordenaba, "cuando los indios por si o por su Capitán y Cacique o protector piden por su conveniencia el que se les dé en qué trabajar, no permita se repartan a mitas; y que, cuando se haga, sea con el justo estipendio, según la carestía de la tierra y sin divertirlos a distancia larga ni en días festivos ni de noche", (118).

La existencia de indios forasteros se verifica en el último cuarto del siglo XVII. Indios que, "voluntariamente, reconociendo la buena paga y agasajo, se convienen en cuidar ganados y cultivar las tierras, y que estos son de los forasteros que hay en aquel reino, por cuya causa no puede haber queja en los encomenderos, pues sólo se sirve la religión de dichos forasteros". (119). Al margen de las encomiendas, se empieza a gestar una nueva categoría social, el inquilino, (120), que arrendaba un pedazo de tierra en las haciendas, que perjudicará a estas últimas, denunciaba el fiscal Martín de Jáuregui en 1744. El inquilino, en algunos casos, por presión de nuevas villas se transformó de arrendador en poblador, en pleno siglo XVIII, afectando los ingresos de los hacendados, (121).

La política de la Corona se mantuvo respecto a la creación de pueblos de indios, prohibiéndose, por R.C. de 26 de abril de 1703, que el encomendero residiera en ellos. Esta disposición encontró resistencia, también, en ese mismo siglo, por parte del gobernador Francisco Ibañez de Peralta. Pero, lo que más repercutió a las tierras de pueblos de indios fue la ocupación de ellas por la erección de las nuevas villas de españoles que caracterizó a los gobernadores del siglo XVIII, distinguiéndose en tales proyectos los nombres de Manso Velasco y Ortíz de Rozas cuyas disposiciones incidieron directamente en las tierras de indios (122). Otras medidas motivaron inestabilidad de la propiedad territorial de hacendados (123).

La población había experimentado cambios apreciables. Alrededor de 1740 se estimaba una equivalencia de 120.000 habitantes, españoles y otro tanto de indios araucanos. En 1778 se daba una población total de 234.138. En tiempos de O'Higgins, en 1791 , se determinaba una población de 308.846 en Santiago y Concepción, y un total de 95.504 indígenas en 1796 (124). La población negra se estimaba en 25.000 a fines del si- 
glo XVIII, (125). Al africano se le había extendido sus beneficios, por parte de Carlos III, y podía adquirir la libertad pagando a su amo su importe y hacerse de un patrimonio con su propio trabajo y mejorar su situación en el aspecto penal (126).

La introducción del elemento vasco que irá a conformar la denominada aristocracia castellana-vasca fue el hecho más significativo en materias sociales en el curso del siglo XVIII, haciendo converger los títulos de Castilla con el empuje empresarial o de poderío económico, conformando el principal grupo social del país (127).

Bajo el signo del despotismo ilustrado se ampliaron las actividades económicas. El trigo posibilitaba la intervención de transportistas y bodegueros al lado de agricultores, aunque la actuación de los bodegueros no estuvo exenta de fraudes a los últimos, (128). La actividad marítima fue estimulada por los astilleros de Nueva Bilbao, San Vicente y otros, (129), y por el gobernador O'Higgins, que fomentó la pesca en el norte del país, en 1789.

Cabe señalar que la sociedad del siglo XVIII fue más rígida en la estratificación social gravitando fuertemente los prejuicios raciales y sociales. Se consideraban oficios indecorosos los de carnicero, pregonero y verdugo, según disponía la Ordenanza Militar de 1768, mientras eran considerados honestos y honrados, por R.C. de 18 de marzo de 1783 , los oficios de curtidor, herrero, sastre, zapatero, carpintero, etc. (130).

Si en el campo se distinguieron dos tipos de trabajadores libres, el peón y el inquilino, en la minería, entre Copiapó y Aconcagua, se emplearon dos sistemas para incrementar la mano de obra, la "dobla" que consistía en que el trabajador saque, "para su beneficio el metal que queda en un tiempo determinado de días u horas" mientras, el otro era el préstamo de una "labor", pactado de palabra, y que debía ser devuelto cuando lo exigiese su dueño. Este último derivó hacia el régimen del salariado, estudiado ampliamente en el sector minero mencionado, por Marcello Carmagnani (131), y el beneficiario del préstamo se convertiría en peón.

En el mismo sector minero se daba paso a una modificación de la propiedad en 1795, al permitirse la propiedad privada de las minas de azogue, cuya producción debía ser negociada con los representantes de la Corona "para su distribución a los mineros interesados, que beneficiaban la plata" (132).

Este paso en la evolución del trabajo y la legislación concerniente fue concluido en la etapa colonial del país, con la liquidación de la fuente perenne de abusos y atropellos que se había convertido la encomienda, a pesar de las denuncias y las medidas legales adoptadas. La superación de tal situación fue debida a un viaje realizado por el gobernador Ambrosio O'Higgins a las provincias del norte de Chile, en octubre de 1788. Lo visto le decidió a adoptar la medida que ya abrigaba con antelación al viaje. La observación de la cruda realidad del indígena en la encomienda la hizo saber, dos meses después de dictaminar la supresión de la misma, al Rey: lo que se llamaba encomienda en estas partes no eran unos pueblos cuyo tributo había decido V.M. a aquellos vecinos en re- 
compensa de los servicios de sus mayores sino un número de infelices que escriptos por lo regular a la circunferencia de las casas, oficios que forman las haciendas de los encomenderos trabajan todo el año sin intermisión en las minas, en los obrages, en la labranza de los campos y en todo cuento era de la comodidad y ventaja de estos que llamaban sus amos para que nada faltase a la esclavitud a que estaban reducidos esta grande porción de vasallos de V.M. y que sin embargo se les obligaba, y estos infelices prestaban como una obligación de que el sustraerse por medio de la fuga costaba presiones, golpes, azotes y cuando podía irrentar la tiranía y el abuso más abominable", (133).

El decreto de abolición de la encomienda fue dictado por el gobernador en La Serena, el 7 de febrero de 1789 , quedando prohibido el servicio personal de los indios encomendados, aunque el derecho de los encomenderos para percibir tributo quedó salvaguardado, ordenando, a los pocos días, una nueva reducción de los indios a pueblos, (134). Esta última disposición de gran trascendencia , aunque tardó su dictación, (135), cerraba la evolución de leyes sociales en el Reino de Chile. El 10 de junio de 1771, una real cédula declaró abolidas las encomiendas e incorporadas a la Corona (136). El mundo laboral se mantuvo inalterable hasta avanzada la era republicana del país, fundamentalmente, en el sector agrario.

\section{NOTAS.}

(1) Francisco Esteve Barba: Descubrimiento y conquista de Chile, Tomo XI, de la Historia de América y de los pueblos americanos dirigida por Antonio Ballesteros y Beretta. Salvat editores. 1946,84.

(2) Paul Rivet y H. Arsandaux, "La métallurgie en Amerique precolombienne". Travaux et Mémoires del 'Institut d' Ethnologie. Vol. XXXIX. París. 1946, citado por José Alcina Franch: "La producción y el uso de metales en la América precolombina" en La minería hispana e Iberoamericana. Contribución a su investigación histórica. VI Congreso Internacional de Minería. Cátedra de San Isidoro. León. Vol. I,315.

(3) Vid Osvaldo Silva Galdames, en Varios: Historia de Chile. Editorial Universitaria. Chile. 4 Tomos. 1974. Tomo I, "Prehistoria".

(4) Benjamín Vicuña Mackenna: El Libro de la Plata. 1 Ed. 1882. 2a Ed. Editorial Francisco de Aguirre. Argentina. 1978,5.

(5) Vid. Gonzalo Fernández de Oviedo: Historia General y Natural de las Indias. Edición y estudio preliminar de Juan Pérez de Tudela Bueso. Madrid. 1959. B.A.E. Tomo 121, (V), Libro XLVII. También Almagro había observado la producción de maíz y los muchos ganados en los valles de Copiapó y Coquimbo, como refiere Oviedo en el capítulo IV, del citado Libro. 
(6) Ciriaco Pérez Bustamante: "Las minas en los grandes geógrafos del período hispánico" en La Minería hispana e lberoamericana, op. cit. 299.

(7) De acuerdo al cronista Diego de Rosales, "el tributo anual que rendían al inga... los chilenos fue de catorce quintales de oro azendrado, de más de veintidós quintales y medio, en tejos de a cincuenta pesos... El último tesoro que cerca del Cuzco embargó y repartió entre sus soldados el adelantado don Diego de Almagro era de mil doscientos libras de oro y entre ellas llevaban dos granos que el uno pesaba setecientos pesos y el otro más de quinientos", citado por Benjamín Vicuña Mackenna: La Edad del Oro en Chile. 1 Ed. 1881. 2a Ed. Editorial Francisco de Aguirre. 1968,9-10.

(8) Véase, Jaime Eyzaguirre: Historia de Chile. Zig-Zag. 1973, Tomo I, 32-33; Francisco A. Encina-Leopoldo Castedo: Resumen de la historia de Chile. Zig-Zag. $8^{\circ}$ Ed. 1970. Tomo I; Francisco Esteve Barba, op. cit. capítulo II.

(9) Cartas de Pedro de Valdivia que trata del descubrimiento y conquista de Chile en Crónicas del Reino de Chile. Edición y estudio preliminar de Francisco Esteve Barba. Madrid. 1960.B.A.E. Tomo 131,11.

(10) Francisco Esteve Barba: Descubrimiento y conquista de Chile, op.cit.320. Nos guiamos de la cifra proporcionada por Alvaro Jara, que sigue el seguro estudio de Thomas Thayer Ojeda. 18 desfavorecidos representaba el $12 \%$ del total de 150 hombres que componían la empresa de Valdivia, de los que 12 "no recibieron encomienda y los otros 6 no la tuvieron nunca "Alvaro Jara : Guerra y Sociedad en Chile. 1 Ed. París. 1961, 2 Editorial Universitaria Chile. 1971,22 Esteve Barba, op.cit. Tomo XI, indica 19.

(11) Cartas de Pedro de Valdivia, op.cit.6. Carta de 15 de septiembre de 1551.

(12) Cartas, op.cit.60.

(13) Vid.F.A.Kirpatrick: "The landless encomienda". The Hispanic American Historical Review Vol. XXII. №4. Nov. 1942, 765-774, traducido al español "La encomienda sin tierras", Revista Chilena de Historia y Geografía. 1943. №102,363374.

(14) Silvio Zavala: Estudios indianos. El Colegio de México. 1948, 302.

(15) Silvio Zavala: La encomienda indiana. Junta para ampliación de estudios e investigaciones científicas. Centro de Estudios históricos. Madrid. 1935, 2. El propósito de bien espiritual y temporal de los indios se manifestaba antes de su incorporación legal en la Recopilación de 1680, Ley. 1,Tit.9,Lib.VI, definida por Zavala, como "un intento posterior de recubrimiento moral y justificación de la institución", op. cit. 276-277. 
(16) En carta de 15 de octubre de 1550, fechada en Santiago, Valdivia le hace saber al Rey, "la principal cosa que conviene que haga cualquier gobernador en descargo de la cesárea conciencia", cuando se refiere a los propósitos de protección indígena de la Corona. Cartas, op. cit. 40.

(17) Citado por Rubén Vargas Ugarte: Historia general del Perú. Editor Carlos Milla Batres.Lima.1971. Tomo II,31. Aquello era una infracción a la Real Provisión "para que ninguna persona que tuviere indios encomendados los puede echar a las minas", expedida en Valladolid el 7 de febrero de 1549, en Richard Konetzke: Colección de documentos para la historia de la formación social de hispanoamérica 1493-1810. Consejo Superior de Investigaciones Científicas. Madrid. 1953, Vol. I, 251-252.

(18) "Jerónimo Núñez con Luis Moreno de Paredes, sobre indios. 8 de enero de 1575", en José Toribio Medina: Colección de documentos inéditos para la historia de Chile. Imprenta Elzeveriana. Chile. 1899. Tomo XIX,6.

(19) José Toribio Medina, op. cit. 84.

(20) José Toribio Medina,op. cit. 85.

(21) Jaime Eyzaguirre, op. cit. 107. Cabe destacar acá que en contraste con lo afirmado por Valdivia en carta de 4 de septiembre de 1545, sobre los anaconcillos, existía la Real Cédula "para que los indios anaconas sean libres, dada en Fuenzalida, el 26 de octubre de 1541, donde se declaraba que los indios que, "se llaman anaconas, los cuales son libres; y que ellos por ser aficionados a los españoles de su voluntad muchos viven con ellos y los sirven y que vos las dichas nuestras justicias, no lo pudiendo ni debiendo hacer", Richard Konetzke, op. cit.Vol. 205.

(22) Ramón L. Soriano: "Perfil político de Pedro de Valdivia". Anuario de Estudios Americanos. Sevilla. 1977. Tomo XXXIV, 463. Para Soriano, "el conquistador fue coadjutor de la explotación de la mano de obra en las encomiendas, conforme a las disposiciones de la Corona, y, asimismo, aplicó las rígidas normas de guerra, conforme al derecho bélico al uso de la época. No aparece en los documentos que hemos utilizado que Valdivia hiciera la conquista por su cuenta, cebándose en la depredación de los bienes de los naturales o en la extenuación de éstos para obtener las máximas riquezas posibles al suelo chileno". op. cit. 463.

(23) Alonso de Góngora Marmolejo: Historia de Chile. Libro I, Parte segunda, Cap. XXXIX, en Crónicas del Reino de Chile, op. cit.322. También, B. Vicuña Mackenna: La Edad del Oro, op.cit.Capítulo segundo.

(24) Eugenio Pereira Salas: "Las ordenanzas de minas del Gobernador de Chile, don Francisco de Villagra". Revista de Historia de América. Instituto Panamericano de Geografía e Historia. México. Diciembre de 1951. № 32,207. Existieron unas 
Ordenanzas primitivas destruidas por el ataque indígena a Santiago el 11 de septiembre de 1541 .

(25) "Ordenanzas de minas. Acta del Cabildo de Santiago de 9 de enero", en Alvaro Jara: Fuentes para historia del trabajo en el Reino de Chile. Universidad de Chile. 1965. Tomol, 1-8. Que el indio pudiera labrar minas lo confirmaría la Real Cédula , fechada en Madrid, de 17 de diciembre de 1551, "que los indios puedan tener y labrar minas de oro y plata como los españoles", en Richard Konetzke, op. cit.

(24) Eugenio Pereira Salas: "Las ordenanzas de minas del Gobernador de Chile, don Francisco de Villagra". Revista de Historia de América. Instituto Panamericano de Geografía e Historia. México. Diciembre de 1951. № 32,207. Existieron unas Ordenanzas primitivas destruidas por el ataque indígena a Santiago el 11 de septiembre de 1541 .

(25) "Ordenanzas de minas. Acta del Cabildo de Santiago de 9 de enero de 1546", en Alvaro Jara: Fuentes para la historia del trabajo en el Reino de Chile. Universidad de Chile. 1965. Tomo I,1-8 Que el indio pudiera labrar minas lo confirmaría la Real Cédula, fechada en Madrid, de 17 de diçiembre de 1551, "que los indios puedan tener y labrar minas de oro y plata como los Españoles", en Richard Konetzke, op. cit.. I, 297.

(26) "Ordenanzas para las minas de plata, presentadas por Antonio Nuñez al Cabildo. Acta del Cabildo de Santiago de 9 de agosto de 1550", en Alvaro Jara: Fuentes, op, cit. 9 .

(27) Ibid. 11

(28) Ibid. 9-10-

(29) "Relación de la orden que en este Reino de Chile se tiene, y de la labor de las minas de oro y quinto dello y otras cosas tocantes á la Real Hacienda" en José Toribio Medina: Colección, op. cit.Santiago.1901. Tomo 28, 355.

(30) Alamiro de Avila Martel: "La propiedad minera en el derecho indiano. Sus bienes constitucionales y peculiaridades". Historia. Instituto de Historia. Universidad Católica de Chile. 1969. № 8,13.

(31) "Real Cédula comunicada al Adelantado don Jerónimo Alderete, Gobernador de Chile, sobre los beneficios de las mina de aquella provincia. 4 de Septiembre de 1555", en José Toribio Medina: Colección, op. cit. Tomo 28,22 y ss. Existe otra copia, al menos por lo que reza su título "Real Cédula dirigida a D. Jerónimo Alderete, gobernador de Chile sobre obtener mayores beneficios de las minas de aquel territorio", sin datar, que trata de la misma, en Colección de documentos inéditos, relativos al descubrimiento, conquista y colonización de las posiciones 
españolas en América y Oceanía, sacados en su mayor parte del Real Archivo de Indias. Madrid. Imprente Española. Reprinted Krauss Reprint Ltd. Vaduz. Tomo 7. (1867), 346-347.

(32) Carlos Olguín Bahamondes: "Condición Jurídica del indígena de Chiloé en el derecho indiano". Revista Chilena de Historia del Derecho. 1978. № 7,162-3.

Aun así, los indios encomendados en Chiloé,según ordenaba Felipe IV, el 17 de julio de 1622, estuvieron afectos a pagar tributación. Disposición regia recogida en la Ley 15, Título XVI, del Libro VI. Cf. Recopilación de Leyes de los Reynos de las Indias. Madrid, MDCCLXXXXI, Tomo II, folio 319.

Los indios encomendados en Chiloé protagonizaron la sublevación de 17121713.Cf.R.C. de 9 de noviembre de 1713, en Alvaro Jara-Sonia Pinto, Fuentes para la historia del trabajo en el Reino de Chile. Legislación 1546-1810. Ed. Andrés Bello, 1983, Tomo II,52-53.

(33) Los encomenderos habían reemplazado el "pago de tributos por los trabajos forzados en las minas". J.H. Elliot: La España Imperial 1469-1716. Vicens-Vives. $7^{\circ}$ Reedición. 1982,73. Existía una Real Provisión "para que no se echen las indios a las minas", dado en Talavera, el 26 de Julio de 1541. Richard Konetzke, op.cit.Vol. I, 201-202.

(34) Pedro Mariño de Lobera: Crónica del Reino de Chile en Crónicas del Reino, op.cit. 275.

(35) Richard Konetzke, op.cit. Vol. I, 297.

(36) Rolando Mellafe: La esclavitud en hispanoaméricana. Eudeba. 1964,23. El empleo de negros en lavaderos de oro, verbigracia, Curahoma o Valdivia, ha señalado Mellafe, producía una gran rentabilidad, "que en un año de trabajo un negro podía pagarse por si mismo", op. cit. 71. Tales posibilidades llevaban a la formación de verdaderas empresas como fue la establecida entre Jerónimo de Alredete y Antonio de Erazo, secretario del Rey, donde ambos participaban con un determinado número de esclavos. Vid. Alonso de Góngora

Marmolejo, op.cit.124 En tales labores se adoptó el procedimiento de mita que fijaba turnos anuales en el trabajo y que era forzado. Sobre la mira una síntesis expositiva la expone Jose M. Valega: El Virreynato del Perú. Historia acrítica de la época colonial en todos sus aspectos. Editorial Cultura Ecléctica. Lima. 1939, 187-203.

(37) La concesión de indios otorgada a Luis Martinez Vegazo el 22 de enero de 1540 fue una de las más ricas de la región. Más tarde, a fines del siglo XVI, Francisco Loayza empezó a explorar las minas de plata de Huantajaya que fue ampliado 
por su hijo Bartolomé a partir de 1718. En la mina Candelaria de Huantajaya en 1793 había una utilización masiva del negro. Consúltese, Sergio Villalobos R: La Economía de un desierto. Tarapacá durante la Colonia. Ed. Nueva Universidad. 1979, capítulo II,VI y VIII. Sobre Huantajaya, también, se refiere Modesto Bargalló: La Minería y la metalurgia en la América española durante la época colonial. F.C.E. 1955, 215 y 298.

(38) Alvaro Jara: El salario de los indios y los sesmos del oro en la Tasa de Santillana. Universidad de Chile. 1961,16.

(39) Santillan señala los maltratos a los indígenas, describriéndolos, "aprerreando muchos, y otros quemando y encalándolos, cortando pies y manos e narices y tetas, robándoles sus haciendas, estrujándoles sus mujeres e hijos, poniéndolos en cadenas con cargas... en siete a ocho años, les quitaban los encomenderos sus hijos y hijas y se los llevaban a las minas", en "Relación de lo que el Licenciado Fernando de Santillan, Oidor de la Audiencia de Lima, proveyó para el buen gobierno, pacificación y defensa de Chile. 4 de junio de 1559", incluido en Alvaro Jara; El salario op. cit. Apéndice documental, 95 y 97.

(40) "Relación de lo que el Licenciado Fernando de Santillan..." op. cit. 98.

(41) Ibid. 99-100.

(42) "Relación de lo que el Licenciado Fernando de Santillan...",op. cit. 105.

(43) "Relación...", op.cit.98.

(44) Alvaro Jara: El salario, op.cit. Cap. II "El funcionamiento positivo de la Tasa de Santillán: Los ganados de las comunidades indígenas provenientes de los sesmos".

(45) Vid. Alvaro Jara: El salario, op.cit.Cap. II, apartado 2,42-46: "La desvirtuación de la Tasa de Santillán: Los sesmos transformados en modalidad de crédito en favor de la sociedad española".

(46) Vid. el análisis de Alvaro Jara en Guerra y sociedad, op. cit. Cap.II: "El régimen señorial español en el orden económico", 27-43.

(47) José Armando de Ramón Folch:"La sociedad española de Santiago entre 1581 y 1596 (Estudio de Grupos)". Historia. Instituto de Historia. Universidad Católica de Chile. 1965. № 4, cuadro 3, página 198.

(48) Vid. Mario Góngora: Encomenderos y estancieros. Estudios acerca de la constitución social aristocrática de Chile después de la conquista 1580-1660. Ed. Universidad de Chile. Sede Valparaíso 1970. También la recensión de Fernando Silva 
Vargas en Historia. Instituto de Historia. Universidad Católica de Chile. 1971. № 10,430 .

(49) Manuel Salvat Monguillot: "La legislaçión emanada de los Cabildos Chilenos en el siglo XVI". Revista Chilena de Historia del Derecho. 1969 № 5,107. El estudio de Salvat Monguillot va en páginas 97-132 y retoma con más detenimiento lo expresado por Julio Alemparte en El Cabildo de Chile colonial. Orígenes municipales de las repúblicas hispanoamericanas. Andrés Bello. 1966. $2^{\circ}$ Edición.

(59) Así lo determinaba la Real Cédula, "sean preferidos los hijos y nietos de conquistadores en los premios y repartimientos de encomiendas", dada en Madrid, el 17 de diciembre de 1621. Richard Konetzke, op. cit. Madrid 1958, Vol. II, 269.

(51) Vid. Julio Alemparta: El Cabildo en Chile colonial, op.cit. Capítulo Cuarto: "La regulación económica", 117-196.

(52) Vid. Bernardino Bravo Lira: "Oficio y Oficina, dos etapas en la historia del Estado indiano": Revista Chilena de Historia del Derecho. 1981. № 8, 76-77.

(53) Acuerdos del Cabildo de Santiago tocantes a diversas material. Acta del Cabildo del Santiago de 1 de julio de 1552 en Alvaro Jara: Fuentes, op. cit. 177.

(54) Acuerdos del Cabildo de Santiago respecto a las minas de oro y aranceles de herreros. Acta del Cabildo de Santiago de 10 de diciembre de 1548 en Alvaro Jara: Fuentes, op. cit. 176.

(55) Gabriel Guarda O.S.B: Historia Urbana del Reino de Chile. Andrés Bello. 1978. "Artesanado e inquilinaje" 195.

(56) Sobre la figura del jesuita bávaro, remito a la monografía de Walter Hanisch S.J., "EI P. Carlos Haimbhausen S.J. Precursor de la industria chilena". Jahrbuch fur Geschichte von Staat, Wirtschaft und Gesellschaft Lateinamerikas, Koln-Wien, 1973, Band 10.

(57) Citado por Hernán Godoy: Estructura Social de Chile. Edit. Universitaria. Chile. $1971,23$.

(58) Carlos Sempat Assadourian: "Chile y el Tucumán en el siglo XVI. Una correspondencia de mercaderes". Historia. Instituto de Historia. Universidad Católica de Chile. 1970 . № 9,70 y ss.

(59) Citado por Silvio Zavala: El servicio personal de los indios en el Perú (extractos del siglo XVI). El Colegio de México. 1978. Tomo I,27. 
(60) Vid. Gonzalo Vial Correa: "Teoría y práctica de la igualdad en Indias". Historia. Instituto de Historia. Universidad Católica de Chile. 1961. №1,104.

(61) Eugenio Pereira Salas, op.cit.213.

(62) Id. 221.

(63) "Ordenanzas que hizo Pedro de Villagra, gobernador de Chile, aprobando las del licenciado Hernando de Santillán en favor de los indios de Chile, 12 de diciembre de 1563" en Alvaro Jara: Fuentes, op. cit, 41-44. Confunde el historiador Demetrio Ramos las disposiciones de Francisco de Villagra con la de Pedro de Villagra, basándose en Agata Gligo Viel, Vid. Demetrio Ramos: Minería y comercio interprovincial en hispanoamérica (siglos XVI, XVII y XVIII). Seminario de Historia de América. Universidad de Valladolid, 1970,67. Es de lamentar la omisión del libro de Alvaro Jara Fuentes, op. cit. en el examen de las disposiciones legales coloniales de Chile.

(64) Rolando Mellafe: "Evolución del salario en el Virreinato peruano (Esquema y sugerencias)". Ibero-Americana Pragensia. Universidad Carolina de Praga. Año I. 1967,96 .

(65) "Ordenanzas dictadas por el licenciado Melchor Calderón para los negros del reino de Chile. 10 de noviembre de $1577^{\prime \prime}$ en Alvaro Jara: Fuentes, op. cit. 44-77.

(66) Manuel Salvat Monguillot: "La legislación emanada de los Cabildos Chilenos en el siglo XVI". Revista Chilena de Historia del Derecho. 1969. №5,107.

(67) Vid. Antonio de Egaña S.I.: Historia de la Iglesia en la América española. Desde el descubrimiento hasta comienzos del siglo XIX Hemisferio Sur B.A.C. 1966,209 .

(68) José Toribio Medina: Colección de documentos inéditos para la historia de Chile, op. cit. Tomo 19,99.

(69) Manuel Salvat Monguillot: "Las funciones de gobierno de la Audiencia en el Reino de Chile". III Congreso del Instituto de Historia del Derecho Indiano, Madrid $17-23$ de enero de 1972. Actas y Estudios. Instituto Nacional de Estudios Jurídicos. Madrid. 1973, 600. El estudio de Salvat Monguillot corre en páginas 597622.

(70) Mario Góngora: El Estado en el derecho indiano. Epoca de fundación (14921570). Ediciones Universidad de Chile 1951,58.

(71) Alonso de Góngora Marmolejo, op. cit. 468. Fernando Campos Harriet se ha preguntado respecto a tal localización en Concepción se "¿fue entonces la Capital 
de Chile?". Vid. Concepción y su historia, Santiago de Chile. 1971, Capítulo III: Asiento de la primera Real Audiencia.

(72) Alvaro Jara: Fuentes, op. cit. 191.

(73) Alvaro Jara:Fuentes, op. cit. 195.

(74) Alvaro Jara: Fuentes, op. cit. 194.

(75) Antonio de Egaña, op. cit. 214.

(76) Agata Gligo Viel: La tasa de Gamboa. Facultad de Ciencias Jurídicas, Políticas y Sociales. Universidad Católica de Chile. 1962, primera Parte, Capítulo Tercero: "Fines de la asa de Gamboa", 67-100.

(77) Agata Gligo Viel, op. cit. 103.

(78) Agata Gligo Viel, op. cit. 108.

(79) Fernando Silva Vargas: Tierras y Pueblos de Indios en el reino de Chile. Esquema Histórico-Jurídico.

Facultad de Ciencias Jurídicas, Políticas y Sociales. Universidad Católica de Chile. 1962,89. Respecto del Corregidor, Fernando Campos Harriet ha precisado la diferencia entre el corregidor, "autoridad territorial representativa de la Corona", y el corregidor de indios, que algunos autores anglosajones han confundido indicando los abusos de este último haciéndolo extensivo con el primero.

Vid. "La institución del Corregidor en el Reino de Chile" 씨 Congreso del Instituto Internacional de Historia del Derecho, op. cit. 675-696.

(80) Fernando Silva Vargas, op. cit. 89, citando CDIHCH, 2da. serie, tomo III, op. 63.

(81) Agata Gligo Viel, op. cit. Cuarta Parte, Capítulo primero: acción frente a la Tasa de Gamboa", 201-211.

(82) Fernando Silva Vargas, op. cit. 91. El estudio de Silva Vargas sobre la materia es fundamental y el mejor logrado.

(83) "Real Cédula en que Felipe II se queja acremente ante el Obispo de la Imperial de que no le hubiera dado cuenta del inhumano tratamiento a que los encomenderos de Chile sometían a los naturales, 27 de mayo de 1582" en Alvaro Jara; Fuentes, op. cit. 200.

(84) Jaime Eyzaguirre, op. cit. 109. 
(85) Rolando Mellafe: La introducción de la esclavitud negra en Chile. Tráfico y rutas. Citado por Fernando Silva Vargas, op. cit. página 94, nota 153.

(86) Vid. Alvaro Jara: Fuentes, op. cit. 61. El mismo día, 4 de febrero de 1593, Oñez de Loyola daba su "Instrucción y ordenanza para los protectores de indios", cuyo texto se halla en Jara, op. cit. 63-67.

(87) En tal comunicación se ponía de manifiesto que, "con poco trabajo podrían apoderarse de todo lo de Chile, donde se entiende que tienen puestos los ojos, porque aquella tierra está de guerra con los naturales y falda de gente y de cabeza que gobierne", citado por Alvaro Jara: Guerra y sociedad, op. cit. 114-115. Consúltese el Capítulo V: "El fracaso del sistema bélico privado y la crisis de fines del siglo XVI", 113-128.

(88) Jaime Eyzaguirre, op. cit. 96.

(89) Alvaro Jara: Guerra y sociedad, op. cit. 186-187.

(90) Vid. Alvaro Jara: Guerra y sociedad, Capítulo IX: "La justificación doctrinal de la esclavitud de los indios", 186-216.

(91) Carmen Barcona: "Las remesas de metales preciosos desde El Callao a España en la primera mitad del siglo XVII", Revista de Indias. España. Enero-Marzo 1959. Año XIX. №75,64 y 65. También, "Relación del Estado...del Marqués de Guadalcazar. 14 de diciembre de 1626" en Angel de Altolaguirre, Colección de las Memorias o Relaciones que escribieron los Virreyes del Perú acerca del estado en que dejaban las cosas generales del Reino. Imprenta Mujeres Españolas. Madrid, 1930. Epígrafe 104. página 44, y "Relación del Estado... del Marqués de marcena", en Angel de Altolaguirre, op. cit. 201.

(92) "Real Provisión prohibiendo la esclavitud y la venta de los indios cogidos en la guerra de Chile. El Callao, 28 de abril de 1605" en Alvaro Jara: Fuentes, op. cit. 209-211.

(93) "Recomendación del Consejo de Indias sobre que los indios de Chile puedan ser escalvos. 17 de noviembre de 1607" en Alvaro Fuentes, op. cit. 213-215.

(94) Real Cédula inserta en Jara: Fuentes, op. cit. 215-216.

(95) "Ordenanza sobre el trato y normas de trabajo para los indios ocupados en su servicio, hecha por el Provincial de la Compañía de Jesús. 19 de Junio de 1608" en Alvaro Jara: Fuentes, op. cit. 67-71. 
(96) Vid. "Real Cédula del Virrey del Perú en que se manda que la guerra con los indios de Chile sea ofensiva. 13 de abirl de 1625" en Alvaro Jara: Fuentes, op. cit. 234.

Sobre los episodios de la guerra defensiva y la figura controvertida del sacerdote jesuita consúltese, Alonso de Ovalle: Histórica relación del Reino de Chile. Instituto de Literatura Chilena. 1969, Libro 7: "De los sucesos y estado del Reino de Chile hasta el último gobernador que ha tenido"; Fernando Campos Harriet: Alonso de Ribera. Gobernador galante y visionario. Zig-Zag. 1966, Tercera Parte: "El Padre Luis de Valdivia y la guerra defensiva"; Francisco A. Encina-Leopoldo Castedo: Resumen de la Historia de Chile, op.cit. Tomo I, 167-169; Jaime Eyzaguirre: Historia, op.cit.156-8.

(97) "Tasa de ordenanza para el Reino de Chile hecha por don Francisco de Borja, Príncipe de Esquilache, 28 de marzo de 1620" en Alvaro Jara: Fuentes, op. cit.71-89.

(98) Ley 1, Título XVI, Libro VI de la Recopilación de Leyes de los Reynos de Indias, op. cit. Tomo II,ff. ss. 315-316.

(99) Las variadas materias relativas a los indios no encomendables, por ejemplo, que afectaban a los naturales de las provincias de Arauco, Tucapel, Catiray, Coyunchos, Huemira, según consignaba la Ley $\mathrm{V}$ del citado Título y Libro, por corresponder al patrimonio real, no podían ser alquilados ni repartidos en mitas, establecía la Ley 7, pero sí podían ser ocupados, de acuerdo con la Ley 10, "con toda moderación en las cosas de nuestro Real Servicio, que en la guerra defensiva se ofreciesen, y en hacer Fuertes, y repararlos, y aserrar maderas para los Barcos,y que este trabajo se les pague en las cosechas de trigo, que en nuestra estancia se siembra..." Respecto a los indios forasteros, el tenor de la Ley 11, era que podían servir a quien quisieran y podían mudarse cuando quisieran.

Cf.Libro VI, Título XVI de la Recopilación de Leyes, op. cit. Tomo II,ff. ss. 315333.

(100) "Tasa y ordenanza que ha hecho don Francisco Lasso de la Vega, Presidente y Capitán General del Reino de Chile, para el desagravio de los indios naturales del en virtud de Cédula Real de Su Majestad 1635" en Alvaro Jara: Fuentes, op. cit. 127

(101) Id. 128.

(102) Id. 128.

(103) Jaime Eyzaguirre, op, cit. 178. 
(104) Manuel Salvat Monguillot: "El tributo indígena en Chile a fines del siglo XVII". Revista Chilena de Historia del Derecho. 1956. № 1,35.

(105) José Armando de Ramón: "La institución de los censos de los naturales de Chile (1570-1750)". Historia. Instituto de Historia. Universidad Católica de Chile. 1961. № 1,51 .

(106) Vid. Guillermo Céspedes del Castillo: "Las Indias durante los siglos XVI y XVII" en Historia social y económica de España y América, dirigida por J. Vicens Vives. Vicens-Bolsillo. 4 Reedición. 1982,451.

(107) Alonso González de Nájera: Desengaño y reparo de la guerra de Chile. Andrés Bello. 1971. Ejecución Quinta: "Como se ha de limpiar de indios esclavos el Reino de Chile, y que caminos sean los más acertados", 300 .

(108) "Consulta de la junta de guerra de Indias sobre si han de herrar o no los indios que se tomasen por esclavos en la guerra de Chile. Madrid. 24 de abril de 1635" en Richard Konetzke: Colección de documentos, op. cit. Madrid. 1958. Vol.II, 349-352.

(109) Vid. Carlos Oviedo Cavada: "Sínodo diocesano de Santiago de Chile celebrado en 1626 por el Ilustrísimo señor Francisco González de Salcedo". Transcripción, introducción y notas de Fr. Carlos Oviedo Cavada. Historia. Instituto de Historia Universidad Católica de Chile. 1964. №3.351-355.

(110) Vid. el trabajo global de Fr. Carlos Oviedo Cavada: "Sínodos y Concilios chile$\operatorname{nos}\left(\right.$ ( ) $-1961^{\prime \prime}$. Historia.

Instituto de Historia. Universidad Católica de Chile. 1964. №3.

(111) Alvaro Jara-Sonia Pinto: "Fuentes para la historia del Trabajo en el Reino de Chile. Legislación. Tercera parte (continuación). Revista Chilena en Historia del Derecho. 1981. №8,171-172.

(112) Demetrio Ramos, op. cit. 244.

(113) Vid. Fernando Campos Harriet: "Tres casos de composición de tierras". Revista Chilena de Historia del Derecho. 1981. № 8,67-72.

(114) Francisco Nuñez de Pineda y Bascuñan: Cautiverio Felíz y Razón Individual de las Guerras Dilatadas del Reyno de Chile. Colección de Historiadores de Chile. Santiago. 1863. Existe una edición abreviada realizada por Editorial Universitaria. Chile. 
Vid. Sergio Correa Bello: El Cautiverio Feliz en la vida política Chilena del siglo XVII. Andrés Bello. 1965. Capítulo IV. I Representación sobre los problemas del reino de Chile, 87-103.

(115) "R.C. sobre no esclavizar, dar buen tratamiento, conversión y reducción de los indios.

20 de diciembre de $1674 "$ en Alvaro Jara-Sonia Pinto, (nota 111), op.cit.164.

(116) Carlos Olguín. Instituciones políticas y administrativas de Chiloé en el siglo XVIII Editorial Jurídica de Chile. 1971,105.

(117) "R.C. sobre la puntual observancia de las Cédulas que están dadas acerca del alivio y buen tratamiento de los indios. 19 de septiembre de $1675^{\prime \prime}$ en Alvaro Jara Sonia Pinto, (nota 111), op. cit. 165.

(118) "R.C. Sobre la forma en que se ejecutare lo resuelto acerca de que los indios no trabajen por mitas. 28 de febrero de $1679 "$ en Alvaro Jara-Sonia Pinto, (nota 111), op. cit. 172

(119) "R.C. sobre que se ampare a los religiosos de la Compañía de Jesús para que no les quiten los indios forasteros que tienen en sus haciendas. 9 de agosto de 1684" en Alvaro Jara-Sonia Pinto, (nota 111), op. cit. 183-184.

(120) Vid. Mario Góngora: Orígen de los inquilinos de Chile Central. Editorial Universitaria. Chile. 1960.

(121) Vid. Santiago Lorenzo Sch. y Rodolfo Urbina: La política de poblaciones en Chile durante el siglo XVIII. Editorial Roberto Silva Bijit. Quillota 1978, "B. De arrendatarios a pobladores", 47-51.

(122) Fernando Silva Vargas: Tierras y Pueblos, op. cit. Capítulo IX: "La fundación de Villas en el siglo XVIII", 145-155.

(123) En la fundación de San Jerónimo de la Sierra se quitó, sin consentimiento, terrenos a la hacienda de Bartolomé de Valenzuela. Vid. Santiago Lorenzo Sch. y Rodolfo Urbina, op. cit.39-40.

(124) Vid. M. Hernández Sánchez-Barba: "Las Indias en el siglo XVIII" en Historia social y económica de España y América, dirigida por J. Vicens Vives, op. cit. Vol. IV, 276. Jaime Eyzaguirre, op. cit.250.

(125) Jaime Eyzaguirre, op. cit. 258.

(126) María Angélica Figueroa Quinteros: "Apuntes sobre el orígen de las garantías a los derechos humanos en la legislación hispano-chilena". Estudios de Historia de 
las Instituciones políticas y sociales. Editorial Jurídica de Chile. 1967. № 2,85,87.

(127) Vid. M. Hernández Sánchez-Barba:" Las Indias en el siglo XVIII", op. cit. "Las mentalidades sociales ", 336-342, también Juan Beneyto: Historia social de España y de hispanoamérica. Aguilar. 2da. Ed. revisada. 1973, 284-288.

(128) Carlos Ugarte: "El Cabildo de Santiago y el comercio exterior del Reino de Chile durante el siglo XVIII". Estudios de Historia de las Instituciones Políticas y Sociales. Editorial Jurídica de Chile. 1966. №1,18-21.

(129) Francisco A. Encina-Leopoldo Castedo: Resumen de la Historia de Chile, op. cit.Tomo I. Capítulo XXXIV: "La economía chilena durante el período hispano". 395.

(130) Juan Beneyto, op. cit. 315.

Algunas medidas del siglo XVIII dispuestas por la corona sobre el matrimonio con la finalidad de prohibir el enlace entre individuos de diferente posición social que afectaba a indios, mestizos y castizos, merecieron la oposición de la Audiencia de Chile. Cf. Magnus Mörner, Estratificación social hispanoamericana durante el periodo colonial. Institute of Latin American Studies, Stockholm, Research Paper Series, Paper № 28, January 1981, p.8.

(131) Vid. Marcelo Carmagnani: El salario minero en Chile colonial, su desarrollo en una sociedad provincial: el norte chico. Santiago de Chile. 1963.

(132) Demetrio Ramos, op. cit. página 108 , nota 86.

(133) Carta de Ambrosio O'Higgins al Rey. 3 de abril de 1789, citando por Ricardo Donoso: El Marqués de Osorno Don Ambrosio O'Higgins 1720-1801. Ediciones Universidad de Chile. 1941,181.

(134) Fernando Silva Vargas, op. cit. Cap. XII: "La abolición de las encomiendas", 175-187.

(135) Las encomiendas habían ido extinguiéndose en el resto del continente a raíz del incremento de gravamen en el curso del siglo XVII, hasta ser incorporadas de modo definitivo a la Corona el 23 de noviembre de 1718. Vid. M. Hernández Sánchez-Barba: Historia de América. Alhambra Universidad. 1981, Tomo 2, 314.

(136) Alvaro Jara - Sonia Pinto, Fuentes, tomo II, 104-105. 